\title{
Recurrent attacks of vertigo with monocular oscillopsia
}

回舟
Figure Constructive interference in steady-state imaging (A) and MR angiography (B) of the patient in the video
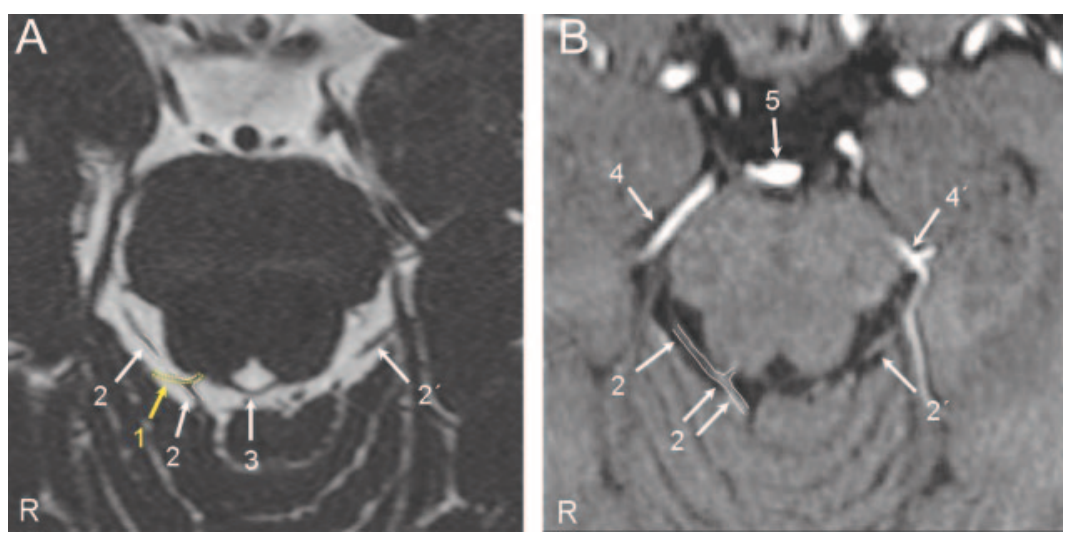

Neurovascular cross-compression between the trochlear nerve (1, yellow dotted lines) and the right superior cerebellar artery (2, white solid lines). 2' left superior cerebellar artery, 3 superior medullary velum, 4/4' right/left posterior cerebral artery, 5 basilar artery.

Supplemental data at www.neurology.org
A 44-year-old woman presented with a 1-year history of recurrent attacks of vertigo lasting several seconds, associated only with oscillopsia. The attacks subsided when she closed her right eye. General clinical and neurologic examinations were normal. The neuro-ophthalmologic investigation showed torsional nystagmus of the right eye with an upward component. An MRI scan (constructive interference in steady-state imaging) showed neurovascular cross-compression between a branch of the superior cerebellar artery and the right trochlear nerve at its root exit zone (figure). The patient was diagnosed with superior oblique myokymia and treated with oxcarbazepine $300 \mathrm{mg}$ BID. At a follow-up visit she was symptom-free.

Katharina Hüfner, MD, Jennifer Linn, MD, and Michael Strupp, MD, Munich, Germany

Disclosure: The authors report no disclosures.

Address correspondence and reprint requests to Dr. Katharina Hüfner, Dept. of Neurology, Klinikum Grosshadern, Ludwig-Maximilians University, Marchioninistr. 15, 81377 Munich, Germany; katharina.huefner@med.uni-muenchen.de 


\section{Neurology}

\section{Recurrent attacks of vertigo with monocular oscillopsia}

Katharina Hüfner, Jennifer Linn and Michael Strupp

Neurology 2008;71;863

DOI 10.1212/01.wnl.0000325477.56089.58

This information is current as of September 8, 2008

\section{Updated Information \&}

Services

Supplementary Material

Subspecialty Collections

Permissions \& Licensing

Reprints including high resolution figures, can be found at:

http://n.neurology.org/content/71/11/863.full

Supplementary material can be found at:

http://n.neurology.org/content/suppl/2008/09/08/71.11.863.DC1

This article, along with others on similar topics, appears in the following collection(s):

MRI

http://n.neurology.org/cgi/collection/mri

Nystagmus

http://n.neurology.org/cgi/collection/nystagmus

Oscillopsia

http://n.neurology.org/cgi/collection/oscillopsia

Vertigo

http://n.neurology.org/cgi/collection/vertigo

Information about reproducing this article in parts (figures,tables) or in its entirety can be found online at:

http://www.neurology.org/about/about_the_journal\#permissions

Information about ordering reprints can be found online:

http://n.neurology.org/subscribers/advertise

Neurology ${ }^{\circledR}$ is the official journal of the American Academy of Neurology. Published continuously since 1951, it is now a weekly with 48 issues per year. Copyright . All rights reserved. Print ISSN: 0028-3878. Online ISSN: 1526-632X.

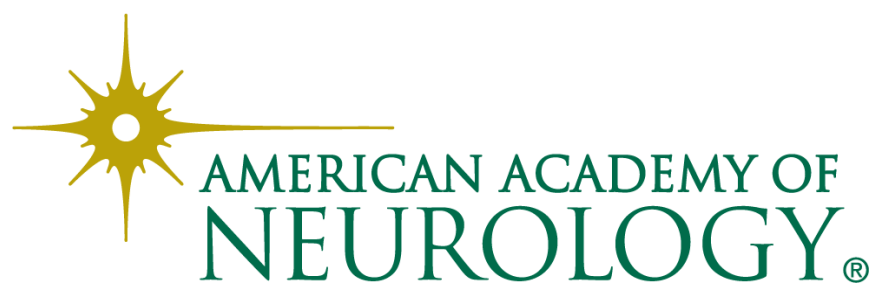

